\title{
The role of grassroots administrators in building international partnerships
}

\author{
A multi-level governance perspective
}

Mei Qu

\begin{abstract}
This article explores how grassroots administrators interact with various other actors in the process of forming international partnerships. A top-down and a bottom-up case of building international partnerships for masters and $\mathrm{PhD}$ programmes were selected from my fieldwork in a Danish university. The cases were elaborated and analysed using Tatiana Fumasoli's organisational approach to multi-level governance in higher education. This article concludes that with their personal networks and knowledge about the normative frameworks of certain powerful actors, grassroots administrators could help academic staff who might not know the regulations involved in the internationalisation process, to balance their own interests with their intention of complying with the normative frameworks, and thus enhance their capacities of forming and participating in a successful international partnership.
\end{abstract}

\section{KEYWORDS}

academic staff, administrators, Denmark, international partnerships, multi-level governance, university

Nowadays, building international partnerships is no longer just an individual academic's personal issue, but involves a variety of actors who come from 'government, education or private sectors' and 'global, national or local domains' (Knight 2008; Knight and de Wit 1997; Marginson and Rhoades 2002; Zha 2003) and who might have conflicting frameworks for collaboration (Knight 2004). Against this backdrop, interactions among actors in the processes of building international partnerships are becoming more and more complicated and unpredictable. The pattern of those interactions has long 
been a topic of concern in previous literature characterised by discussions on the top-down and the bottom-up formation processes. However, a review of the literature presented below shows that the role of grassroots administrators has been largely neglected.

Drawing on Tatiana Fumasoli's (2015b) organisational approach to multilevel governance (MLG) in higher education, I analysed a top-down pattern and a bottom-up pattern of building an international partnership selected from my fieldwork in a Danish university addressed as X University (XU). The article will present a rich description of how grassroots administrators facilitated international partnership formation and demonstrate how Fumasoli's MLG conceptual framework could be used for understanding individuals' roles in organisational development.

\section{Literature review}

\section{The dynamics of building international partnerships and the actors involved}

Regarding the dynamics of building international partnerships, previous literature mainly identified two opposing patterns: the top-down pattern and the bottom-up pattern, both of which explore the interactions between the administrative managers and the academic staff. A top-down pattern of building an international partnership is also called the 'leadership-driven model' (Neave 1992) or 'planned approach' (Edwards 2007). It is initiated by administrative managers at the university or department level. However, previous research reported that such patterns usually turn out to be ineffectual as the top-level administrators' plans are overlooked by grassroots actors (Edwards 2007; Oleksiyenko 2009). By comparison, a bottom-up pattern of building an international partnership, called a 'base unit-driven model' (Neave 1992) or 'opportunistic approach’ (Edwards 2007), is initiated by academic staff. Disappointingly as well, many such initiatives never 'evolve beyond the start-up individuals' (Hudzik 2015: 33). A third pattern suggests that the process of building an international partnership does not move in a linear line, that is, top to bottom or vice versa, but is fraught with unexpected twists and turns (Gieser 2016). James D. Gieser (2016) uncovered how an international partnership starting at the top travelled through its diverse stakeholders who had divergent perspectives and was powerfully shaped by them. Nevertheless, as 
there were only academic staff and senior administrators mentioned in his research, his findings only highlighted once again the tensions between the administrative managers and the academic staff.

While both administrative managers and academic staff are important actors in international partnership formation, academic staff in particular are believed to be the 'catalysts', 'initiators' (Finkelstein et al. 2013), 'champions' and 'mediators' (Horta and Patrício 2016) of partnerships. However, as the actors participating in international partnerships are becoming more diversified, it is necessary to take other actors into consideration. Some researchers included government policy makers in their analysis of top-down international partnerships (Horta and Patrício 2016; Jones and Oleksiyenko 2011; Spencer-Oatey 2013; Tekleselassie and Ford 2019), but there are still many other actors that deserve attention, for instance, the grassroots administrators in universities. Since the mid-twentieth century, there has been a sharp rise in the number of administrative staff in the United States as well as in Europe (Baltaru and Soysal 2018), nonetheless, the majority of them, that is the grassroots administrators, have not been taken as a crucial group in the university internationalisation processes (Brandenburg 2016; Hunter 2018). Are grassroots administrators active or passive actors in international partnership formation? How do grassroots administrators interact with the diverse actors who might have conflicting ideas towards collaboration? In what way do these interactions twist the linear patterns of building international partnership? To answer these questions, it is necessary to adopt an analytical perspective covering various actors.

\section{An organisational approach to multi-level governance in higher education}

Multi-level governance (MLG) theory, initially proposed by Gary Marks (1992, 1993) and subsequently developed by Lesbet Hooghe and Marks (2001), is an approach to deal with the more and more complex and interdependent European Union (EU) governance. It has also inspired researchers to unpack the emerging complexities in higher education. However, only a few authors have discussed MLG from an organisational perspective (Fumasoli 2015a, 2015b; Fumasoli et al. 2014; Fumasoli and Huisman 2013; Jones and Oleksiyenko 2011; Seeber et al. 2015). Among them, Fumasoli's (2015b) conceptual framework is particularly significant to address the research questions of this article as it focuses on the specific actors embedded in institutional and organised settings. 
Based on previous organisational studies (Brunsson and Olsen 1998; Egeberg 2012; March 1999), Fumasoli (2015b) argued that the 'organisation' in her approach 'can be understood as networks whose nodes interlink both inside and outside the organizational boundaries' (86). In that sense, international partnerships are also 'organisations'. She assumed that the 'actors' embedded in such an organisational setting have some specific features, in brief: (1) actors have 'bounded rationality' which means that they are unable to consider all possible alternatives and their consequences (March and Simon 1993; Simon 1965); (2) actors follow a 'logic of instrumentality', on one hand, and a 'logic of appropriateness', on the other hand, meaning that they define their own interests and try to achieve them, while playing an appropriate role based on moral grounds (March and Olsen 1976, 2006); and (3) the 'formal framework' provided by the organisation may empower and shape actors' behaviour (Aldrich and Reuf 2006; March and Olsen 2006; Scott 2008).

Furthermore, Fumasoli (2015b) proposed three key analytical concepts of the organisational approach: organisational structure, membership/identity, and centrality. The 'organisational structure' is a social structure of 'patterns and regularised aspects of the relationships existing among participants in an organisation' (Scott 2003: 18) and it 'reflects how hierarchy and authority are designed and dispersed' (Fumasoli 2015b: 87). The 'membership' criteria refer to the entrance requirements and socialisation processes that stipulate the composition of staff within an organisation. Its related concept, 'organisational identity', has not been clearly defined. However, Fumasoli (2015b) argues that 'leadership quite often designs an organizational identity in line with organizational strategy' (88); however, as members might have multiple affiliations [read as membership] and loyalties, they might comply with the organisational identity only to a certain extent (Fumasoli et al. 2015). 'Organisational centrality' could be understood as the 'capacities to operate' on different levels of the MLG structure. Fumasoli (2015b) posited that actors do not have equal opportunities to participate and influence policy processes in higher education.

Fumasoli's (2015b) theory was put forward mainly based on research that takes the institution of the 'university' as a whole, and there is lack of empirical evidence about how individual actors, such as academics and administrators, connect in MLG. Therefore, Fumasoli (2015b) suggested this knowledge gap as an avenue for further research. Theoretically, this article 
will try to present an example of how Fumasoli's (2015b) theory could be used for analysing the individual actors in and outside of the university.

\section{Method}

The purpose of this article is to study how grassroots administrators interact with diverse actors in the dynamics of building international partnerships. According to Robert K. Yin (2003), a case study design is very helpful when solving the 'how' problem. A 'case' is the 'unit of analysis' (Miles et al. 1994: 25). It could be a person, a group, a location, an organisation, an event (Hayes 2000) or a process (Baxter and Jack 2008). In this study, I selected two processes or cases - a top-down and a bottom-up process of building an international partnership - from recent fieldwork in a Danish university, which had been dedicated to internationalisation over the past decade. As you will read in the findings, the top-down case is about how a grassroots administrator (Jan, pseudonym) helped a department director and an academic (Peter, pseudonym) undertake the institutional mission of collaborating with some Vietnamese partners; and the bottom-up case describes how a grassroots administrator (Amalie, pseudonym) assisted an academic (Charlotte, pseudonym) in initiating an EU-funded international research network. The administrators are the key informants in this study. Nevertheless, to reach a holistic understanding of the two processes, I also interviewed other key actors who were involved, such as the academics who they helped.

In accordance with Matthew B. Miles and colleagues, a 'case' is also defined as 'a phenomenon of some sort occurring in a bounded context' (1994: 25). The boundaries indicate what aspects of the context will and will not be included in the study. As such, I also collected archival records; policy documents produced by XU, the Danish government and the EU, and I interviewed central administrative managers (e.g., Mads, Kurt, Ida, all pseudonyms) who could provide information on the organisational context, especially about the diversified actors that XU was confronted with and about grassroots administrators' status in the university's centralisation and decentralisation reforms. Most of the context information will be delineated in the background section. Some others that are closely related to the specific cases will be mentioned in the findings.

I transcribed all interviews and analysed them with the contextual data and Fumasoli's (2015b) approach. The details of the two cases will be 
displayed in the format of 'networks', a series of nodes or points with links (lines and arrows) between them that display streams of participant actions, events and processes (Miles et al. 1994).

\section{Background}

$\mathrm{XU}$ is one of the biggest comprehensive universities in Denmark. Since 2008, it had published two global-oriented overall university strategies (hereinafter referred to as 'overall strategy') and two university strategies focusing on 'internationalisation' specifically (hereinafter referred to as 'internationalisation strategy'), signifying its ambition in internationalising the university. XU claimed to be 'a leading globally-oriented university with a strong engagement in the development of society' in its overall strategies. To achieve that goal, the strategies said that XU should try to integrate global collaboration into the university's education, research, talent development and knowledge exchange through strong interaction and collaboration with researchers and lecturers, public authorities, non-government organisations and enterprises around the world. Its strategies, which set up the 'formal framework' for internal individual actors and the 'organisational identity' of the university, indicated that XU was a typical MLG organisation that connected with other organisations at multiple levels.

Among the external actors, the European Commission and the Danish government were the most influential ones. Since the launch of the Lisbon Strategy in 2000, the European Commission began to become directly involved in educational policies, which had traditionally been a nationally sensitive policy area in the EU (Ministry of Science Technology and Innovation 2009). In order to gain more 'centrality' in the EU structure, XU claimed in its institutional internationalisation strategies that it should actively react to EU initiatives, such as participating in the Bologna Process and Erasmus programme and winning more international research grants, especially EU FP7 and Horizon 2020 grants.

In 2006, the Danish government issued a globalisation strategy and established a series of university-oriented policy goals (Ministry of Science Technology and Innovation 2009) and thus it became much more deeply involved in Danish higher education. A series of Danish university reforms, such as university mergers and the management reform in which the rector became the head of a strongly line-managed and coherent organisation (Wright 2014), indicated that the Danish government tried to make higher 
education work as efficiently as possible in order to ensure Denmark would be 'globalisation-ready' (Oddershede 2009). In this setting, XU underwent a series of internationalisation reforms which changed the organisational structure of the university.

The first internationalisation reform was a centralised one. The rector and his management team made internationalisation one of the vital development agendas by promoting an institutional internationalisation strategy written by a limited group of internationalisation experts and then approved by the university leaders (interview with Mads, 7 February 2014). Another important measure was setting up the 'internationalisation infrastructure of the university' (interview with Kurt, 26 August 2014) or the administrative units for university internationalisation, represented by a central International Centre which merged a number of functions, namely strategy and international partnerships, PhD and staff mobility, student mobility, and housing. The administrative leaders that I interviewed all thought that the centralised 'infrastructure' was very important because internationalisation no longer just involved individual researchers or individual research groups but became much more complicated and thus the institutional administrative support was indispensable (interview with Ida, 19 March 2014). Along with the establishment of the central International Centre, faculty and department-level administrative units (local units) for internationalisation were also set up in order to form a 'central-local' administration structure. According to central administrators, such a structure enabled the centre (International Centre) to grasp a comprehensive knowledge of the university (Ida, interview, 19 March 2014). But interviews with local administrators and academics indicated they had little knowledge of, or engagement with, this centralised structure.

The university's senior management team had adopted a centralised approach to all aspects of the university, and this had incurred widespread discontent across the university. When a new management team took office in 2014, decentralisation became the trend (Ida, interview, 10 June 2015). '(It was) them [emphasis added by the speaker], the academics, who were to make the real change (to internationalise the university)', said Mads (interview, 7 February 2014). To encourage the academics to be more involved in the internationalisation of the institution, the second internationalisation strategy adopted an academic-centred approach. In this process, eight academic representatives - researchers, study leaders, programme managers within the PhD schools, and vice deans - from different disciplines contributed ideas. The administrators both at the central and local level only 
worked as the 'service group', who listened, took notes and wrote down the academics' ideas (Ida, interview, 19 March 2014). To their surprise, this academic-centred strategy formation process still incurred some sort of dissatisfaction among local grassroots administrators. For example, Jan, a faculty-level international coordinator who will be mentioned in one of the following cases, was unhappy about not being invited to the strategy group. He complained:

It was only the academic group that commented on the strategy because it was a bottom-up approach....That is fine.... When my colleague (who worked in the 'service group') came back from the meeting, she told us what had been discussed, and then I said, 'that sounds crazy because according to, for example, Regulation A, that is not allowed'. So I suggested that when they do that they need to remember to do B in order to avoid violating A. (Jan, interview, 30 April 2015)

These two internationalisation strategies confirmed Fumasoli's (2015b) argument that actors do not have equal opportunities to participate and influence policy processes in higher education. The transition from a centralised internationalisation reform to a decentralised one implied that there was a consensus that academic staff play a pivotal role. However, from Jan's complaint, it seemed that the academic staff who were brought into the process had 'bounded rationality' as they might not know the regulations involved in the internationalisation process. Unfortunately, grassroots administrators like Jan, who had the detailed knowledge of regulations and processes, were always neglected in the internationalisation reforms at XU.

\section{Findings}

\section{A top-down pattern of building an international partnership}

This case discusses the realisation process of a top-down pattern of building an international partnership for higher education (shown as the thick one-way arrow A in Figure 1) in a biological studies department (represented by the big triangle on the left of the Figure) of XU. In XU's internationalisation strategy, it said that the university would aim at 'providing research-based consultancy services concerning global issues, increasing contribution to global welfare through capacity building and participating in the increasingly global innovation'. This had also been the biological department's mission or 


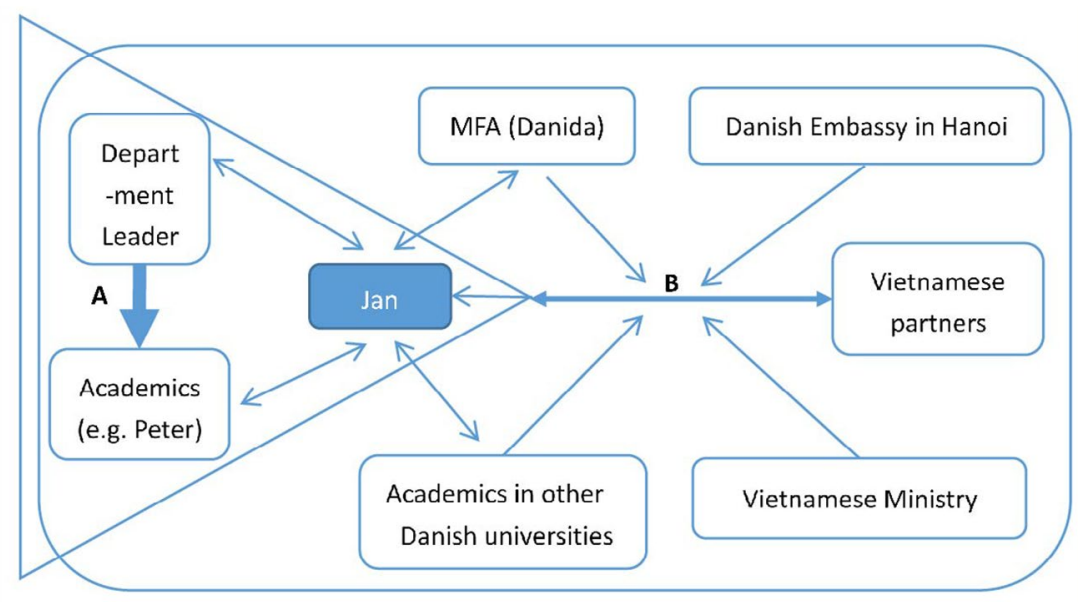

Figure 1. A top-down pattern of building an international partnership

'organisational identity' for a long time. The intention of the departmental leader was to build a collaborative relationship (shown as the double-sided thinner arrow B) between the department and some Vietnamese partners. To make this happen, the academics in this department needed to advocate the departmental leader's proposal and play a key role in this international partnership. Only in this way could the departmental leader's 'centrality' in partnership formation be realised.

Peter was one of the academics that the leader tried to invite on board. To help Peter balance his own interests (logic of instrumentality) with his intention of complying with the department's interests (logic of appropriateness), the leader promised Peter that if he worked in this collaborative programme, then his tenure track would be easier. Therefore, Peter accepted the invitation or complied with the ‘organisational identity'. However, Peter could not get the membership of a successful international partnership by merely following the leader's proposal, as for Peter, getting on board meant entering into 'a new world that had never been on my plan’ (Peter, interview, 29 May 2015). This 'new world' is the unknown 'organisational structure' shown as the big dotted box.

In fact, besides a departmental tradition of doing research and capacity development in tropical countries, the leader's idea of collaborating with the Vietnamese partners was primarily suggested by Jan, an international 
coordinator at faculty level. Jan had more than fifteen years of experience in assisting his academic colleagues in several science and technology departments and occasionally in other disciplinary areas. He helped identify suitable partners, raise funds from the Danish government (e.g., Danish Ministry of Foreign Affairs) or international organisations, and develop projects (especially international projects with partners from developing countries). He not only had a good knowledge of the funders' 'formal frameworks' but also had accumulated a large network of scientific academics. In addition, he understood what the academics were doing by regularly attending meetings where the academics presented their research topics or progress. Sometimes $\mathrm{XU}$ academics also knocked at his door and asked whether he could find some relevant partners from Asian countries to work with. By working with Vietnamese academics and practitioners in another project, Jan realised that the Vietnamese partners in the provinces in Mekong Delta needed 'serious upgrading' by, for instance, a master's programme in environmental science and management. Therefore, he suggested the leader initiate an international collaborative master's programme and Jan's knowledge about the potential funders and Vietnamese partners made him an indispensable actor to facilitate this collaboration in a much larger 'organisational structure'.

One of the most important actors in this new 'organisational structure' was the Danish Ministry of Foreign Affairs (MFA). Jan and the leader decided to seek funding from MFA's Danida programme, a programme for development cooperation. According to Danida's guidelines, the applicants needed to describe the potential benefits to the local community or how the applicants would disseminate their knowledge. Peter said that they would write international peer-reviewed papers or build a website. However, based on the knowledge about Danida and the Vietnamese partners, Jan suggested that popular TV shows, radio interviews, conferences or seminars could be better choices because farmers who did not know English would not read academic papers and poor farmers did not have computers. Therefore, Jan made up for Peter's 'bounded rationality' and helped Peter balance his own interests (logic of instrumentality) with his intention of complying with the department's interests (logic of appropriateness). Jan further explained that 'these (Danida) guidelines were written in a language which was easy for me to understand but slightly different from what scientists normally read' (Jan, interview, 30 April 2015).

Another important group of actors was the academics in the other Danish universities. Jan and the leader reviewed what courses had already been 
taught in the Vietnamese university and what other courses their department could provide. For the courses which were needed in Vietnam but which were not offered in their department or other XU departments, they asked Peter to invite academics from other Danish universities to join the partnership.

The application was approved by Danida. Nevertheless, shortly after they received the first cohort of students, they found that this master's programme was illegal according to the Vietnamese legislation because the curriculum was not yet approved by the Vietnamese Ministry. At that time Vietnamese universities had unified courses across the country, whereas in Denmark the universities had more autonomy on curriculum design. Apart from that, the curriculum for a master's programme in environmental science and management did not even exist in Vietnam. This revealed the 'bounded rationality' of Jan, his Danish colleagues, and the Vietnamese partners. They negotiated with the relevant department in the Vietnamese Ministry and convinced them that this programme was a good idea and discussed how to make it a legal programme. MFA and the Danish Embassy in Hanoi also helped a lot in this process. Finally, a new 'organisational structure' was formally set up (represented by the big dotted box circling all actors involved in this process).

This master's programme ended up being very successful. The XU department and the Vietnamese university continued their cooperation afterwards. Most importantly, for Peter, this random event turned out to be something interesting. When teaching in Vietnam, Peter and his colleague encountered an enormous industry based on air-breathing fish in Vietnam. However, the local people knew nothing about the physiology of these animals, while Peter's department was specialised in respiratory physiology. The collaboration brought Peter not only academic benefit but also some personal attachment. The following quote shows how Peter's own interests ('logic of instrumentality') and his intention of complying with the department's interests (his 'logic of appropriateness') came into balance and this top-down process of building international partnership was successful in the end:

I'd never really expected to find Vietnam interesting. I really didn't. It was there, and you know, it was the other side of the world. It wasn't in my interest in there. And now it is. And that's emotionally enjoyable, on a personal level. (Peter, interview, May 29, 2015)

This case indicates that, firstly administrative managers' (department leader and Jan) centrality in partnership formation cannot be realised 
without the support of academic staff (Peter). Secondly, even though Peter complied with the 'organisational identity' of the department, it did not promise that he could find partners (obtained the membership of the partnership) or his 'centrality' (compacities to operate) in partnership formation is promised. This is because Peter's 'bounded rationality' - unfamiliarity with the formal frameworks upheld by two powerful actors (the funders and the Vietnamese actors) in the new 'organisational structure' - inhibited him from exploring the unknown 'organisation'. It was Jan's expertise as well as the persistent negotiations among various actors that made this top-down way of building international partnership come true and helped Peter achieve a balance between his 'logic of instrumentality' and 'logic of appropriateness'.

\section{A bottom-up pattern of building an international partnership}

This case discusses a bottom-up pattern of building an international partnership (shown as the thick one-way arrow A in Figure 2) in XU (represented by the square in the middle of Figure 2). In 2006, an extensive review of $\mathrm{PhD}$ education was carried out in Denmark and the report 'explicitly recommended greater internationalisation of the doctorate training' (University World News 2010). Therefore, the Danish government's globalisation strategy announced that 0.5 per cent of GNP or 39 billion DKK (US $\$ 7.1$ billion) would be allocated between 2006 and 2012 in order to raise the number of new

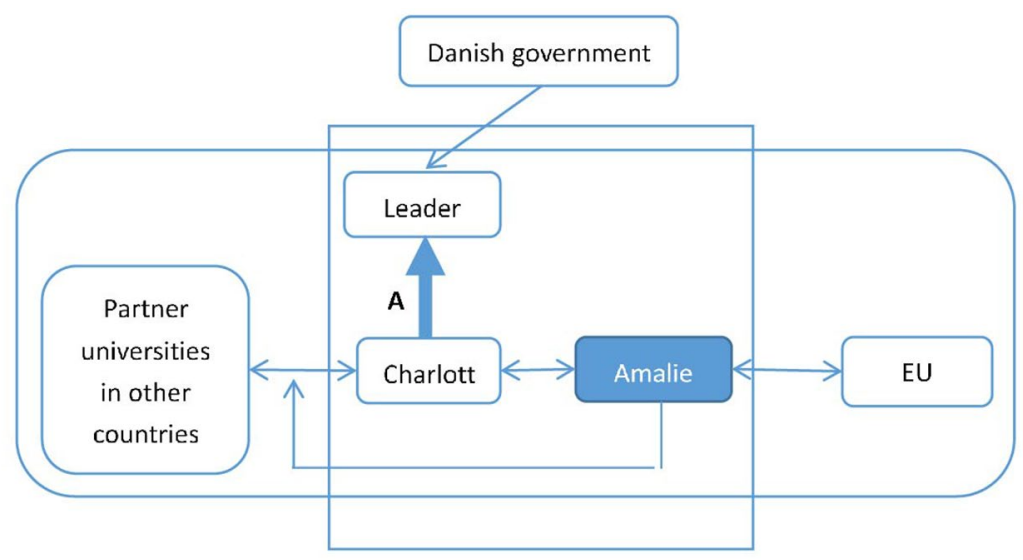

Figure 2. A bottom-up pattern of building an international partnership 
PhD students (University World News 2010). XU's strategy also said that in the $\mathrm{PhD}$ area there would be a need for an increased effort to attract the best talents nationally and internationally. It should be noted that in the globalisation strategy of 2006, the government and the universities made an agreement that 'the growth in PhD priority should be given to the technological sciences, natural sciences, health and information technology' (University World News 2010). Charlotte, a professor working in a social science department had been anticipating that her plan of recruiting more $\mathrm{PhD}$ students would be supported by the university leader. However, unfortunately, her department was not deemed a 'priority' discipline and was not covered by the globalisation policy. Therefore, Charlotte's 'logic of instrumentality' was not recognised at all by the top leaders:

Our department was not allocated PhDs. So when colleagues in the rest of Denmark said, 'I have so many PhD students, and I don't know what to do with them', or 'I'm drowning in PhD students', I was saying, 'well, we live in a $\mathrm{PhD}$ desert [emphasis added by Charlotte]. There's no PhD student here'. (Charlotte, interview, 15 September 2014).

As Charlotte did not benefit from the Danish globalisation strategy on $\mathrm{PhD}$ expansion from her university, she chose to pin her hopes on the EU. This meant trying to obtain an EU 'membership'. Nonetheless, Charlotte said that she could not understand the 'EU language' or the 'formal framework' of EU forms:

I mean the EU language is a language of its own. It looks like English, but it's nothing like English. It's completely its own language. And when you see one of the EU application forms for the first time, it is completely baffling, and you wouldn't know where to start. (Charlotte, interview, 15 September 2014)

Due to this 'bounded rationality', Charlotte turned to Amalie for help. Amalie is a research support officer. She started her career as a project leader for several EU social and regional projects in the international office of a local municipality in Denmark. From that job she learned about 'EU thinking about projects' (Amalie, interview, 16 September 2014), that is, how an EU project should be applied for, set up and reported. Later Amalie was temporarily appointed by the Ministry as an editor for the first Danish FP7 material, which, as she put it, involved distilling the essence of 'millions 
of English documents' about FP7. She was supposed to tell the Danish researchers about FP7 and how to make an FP7 project. After that, she became a national contact person - the contact point at the Ministry between the Danish universities and EU - for some of the programmes in the FP7. She went to Brussels and collected all the briefings and papers from the relevant people, and then she read through everything and made the material available for the researchers who had relevant interests. In late 2009, Amalie was employed by XU to help researchers in a social science department with funding applications and project management. Instead of sitting in the office, waiting for instructions from her boss or demands from the researchers, she took the initiative to visit the researchers, getting to know their research interests, the projects that they were doing and their ideas for funding applications. She noted down the information she collected about various researchers in a little booklet. She subscribed to all kinds of programme newsletters that she thought could be interesting for the researchers and then went to the relevant meetings. She also collected a lot of information from the then national contact person for the EU programmes in which she was interested. She read and screened all kinds of material that she collected, writing down the useful information in the form of newsletters and emailed them to researchers.

Upon Charlotte's request, Amalie suggested a few programmes. After some discussions, they decided to apply for a large programme, but the premise was that they could find more partners. Certainly it was up to the researchers to decide whom they wanted to work with. However, Amalie gave 'some sort of strategic advice' (Amalie, interview, 16 September 2014), and this was accepted and acted upon by Charlotte. The programme that they applied for required that their project should have at least three European partners. However, Amalie suggested that the project should have at least four partners, in case one partner dropped out of the project due to certain unexpected reasons, and at most six partners because if there are more universities, some of the research teams would be too small, and it would be better to have two or more PhDs or postdocs together so that they can help each other in each place. Amalie also suggested that it was better to have partners from Eastern and Southern Europe, because the EU preferred wider geographic coverage, although it was not officially stated.

Amalie also helped a lot when preparing the application documents. She and Charlotte read through the EU archives to see what kind of projects the EU had already funded to ensure that their project was original and meaning- 
ful. She brought all the forms to Charlotte's office and showed the 'innocent' professor how to fill the forms wisely. As Charlotte recalled,

next day she came with the forms. She sat down and said, 'This says it wants this, but in fact, it wants that. And for this, you should fill it in this way'. And then she brought the evaluation criteria for the form and said: 'Look, question number one is evaluated by these criteria, so you need to make sure you've got this information clearly in your answer here so that they will see it and will mark you high'. So she gave me all that support. She knew how to do things in an area that I've never done before. I didn't know how to do this at all. She has the big picture, and she has very detailed knowledge as well. That's just brilliant. (Charlotte, interview, 15 September 2014)

With Amalie's assistance, Charlotte managed to balance her logic of instrumentality and logic of appropriateness and gradually obtain centrality in partnership formation. As a result, a new international partnership, or a new 'organisation' (represented by the big dotted rectangle in Figure 2) was successfully founded, and Charlotte gained access to EU membership. After that, Amalie also set up all the administrative and budget systems for managing the partnership. With Amalie's help, Charlotte not only managed to recruit $\mathrm{PhD}$ students internationally but also built a much larger international research network. Later, this international partnership received administrative support from XU PhD School, and it was advertised as one of XU's flagship $\mathrm{PhD}$ programmes. Thus, a bottom-up way of building an international partnership was accomplished.

In this process, the key obstacle for Charlotte was gaining 'centrality' in partnership formation. When this centrality was not given by the university leader, the EU offered an opportunity for her. However, this new opportunity could not have been acquired without the help of Amalie who understood EU's 'formal framework' and who helped Charlotte balancing her logic of instrumentality and logic of appropriateness.

\section{Discussion}

To explore how grassroots administrators function in the dynamics of building international partnerships, I selected two cases - a top-down and a bottom-up pattern of building an international partnership from the fieldwork in XU in Denmark and analysed them using Fumasoli's (2015b) conceptual frameworks. 
The findings demonstrate that grassroots administrators are indispensable. Drawing on Fumasoli's (2015b) conceptual frameworks, their role could be seen more clearly. In short, either in a top-down or a bottom-up partnership formation process, with their personal network or knowledge about the 'formal framework' of certain powerful actors, grassroots administrators could help academic staff overcome their 'bounded rationality', balance their 'logic of instrumentality' and 'logic of appropriateness', and thus enhance their 'centrality' and obtain 'membership' to a successful international partnership.

This article points out that academic staff might have 'bounded rationality', nevertheless, it does not mean to downgrade academic staff's status in international partnerships. Actually, both the cases prove that academic staff could actively make use of their social networks, which had great influence on partnership formation. The grassroots administrators like Jan and other actors in the top-down case also had 'bounded rationality', and this is a specific feature of every actor in a MLG context (Fumasoli 2015b). The purpose of highlighting academic staff's 'bounded rationality' is to illuminate the necessity of encouraging collaboration between academic staff and grassroots administrators.

Previous research seemed to be pessimistic about the collaboration between academic staff and administrators. For example, Silke Preymann and colleagues (2016) find that academic staff and administrators follow different logics: the former follow a professional academic logic, while the latter follow a corporative administrative logic. Therefore, it is not surprising to find that the literature on dynamics of building international partnerships mentioned before usually focus on the tensions between administrative managers and academic staff. However, this article provides two unusual cases in which the academic staff and grassroots administrators collaborated very well. This finding may not lead to a generalised conclusion, but it suggests a possibility that these two kinds of actors can cooperate.

It should also be noted that grassroots administrators like Jan and Amalie are not ordinary administrators whose undertakings are more rule and routine based, for example, salary administrators, accountants and secretaries (Ryttberg and Geschwind 2017). They are similar to what (Ryttberg and Geschwind 2017) called 'professional support staff' who have knowledge about values and norms in 'business life', or to be precise, from a multilevel governance perspective, they are professional support staff who have knowledge about certain critical and powerful external actors as well as rich 
local knowledge about local strategies, leaders' priorities and academics' disciplinary interests. In addition to their roles in international partnerhsip formation, the findings also describe the efforts they made in order to become professional support staff. It seemed that Jan's and Amalie's expertise were not acquired through any specific training programmes, as Uwe Brandenburg (2016) suggested, but by going between various actors, learning about their characteristics and matching their needs. This kind of communication helped them build a social network through which they gained privileged access to critical information and got the opportunity to forge strategic partnerships (Bleiklie et al. 2015). In view of this, I would like to suggest that more reward mechanisms or opportunities should be created to encourage grassroots administrators to communicate with various actors, especially academic staff.

Last but not least, by following grassroots administrators' interactions with other actors, the findings of this study confirm Gieser's (2016) argument that the dynamics of building international partnerships is fraught with unexpected twists and turns. However, this article provides a more complex picture than Gieser's (2016) - the complexity is not merely a matter of more actors, but also more hierarchies. There was the 'top-down' hierarchy created by university leaders, hierarchies between different disciplines and other 'internal-external' hierarchies which forced academic staff and grassroots administrators to comply with the policy and funding frameworks of powerful national and international actors. In both cases, the grassroots administrators played a crucial role in understanding the different rationalities of these diverse hierarchies and bringing them together in successful partnerships.

\section{Acknowledgements}

This article derives from my $\mathrm{PhD}$ project 'Participatory Internationalization: The Organizational Dynamics of Creating an International University in China and Denmark', funded by the China Scholarship Council and Aarhus University. 
Mei Qu finished her PhD study in Denmark and then worked as a postdoc researcher in Center for China and Globalization (CCG), a non-governmental think tank based in Beijing, China. Now she is an Associate Research Fellow at CCG. She is interested in globalisation and internationalisation of education at a micro level - how individuals were influenced and how they exert agencies. Currently her research mainly focuses on international student mobility, international schools and education for international understanding, which are all critical issues in China's educational opening-up.

Email: qumei5945@foxmail.com

\section{References}

Aldrich, H. E. and M. Reuf (2006), Organizations Evolving, 2nd ed. (London: Sage).

Baltaru, R.-D. and Y. N. Soysal (2018), 'Administrators in higher education: organizational expansion in a transforming institution', Higher Education 76, no. 2: 213-229. https://doi.org/10.1007/s10734-017-0204-3.

Baxter, P. and S. Jack (2008), 'Qualitative case study methodology: Study design and implementation for novice researchers', The Qualitative Report 13, no. 4: 544-559. https://doi.org/10.46743/2160-3715/2008.1573.

Bleiklie, I., J. Enders and B. Lepori (2015), 'Organizations as penetrated hierarchies: Environmental pressures and control in professional organizations', Organization Studies 36, no. 7: 873-896. https://doi.org/10.1177/0170840615571960.

Brandenburg, U. (2016), 'The value of administrative staff for internationalization', International Higher Education 85: 15-17. https://doi.org/10.6017/ihe.2016.85.9239

Brunsson, N. and J. P. Olsen (1998), 'Organization theory: Thirty years of dismantling, and then...?', in N. Brunsson and J. P. Olsen (eds), Organizing Organizations (Norway: Fabokforlaget), 13-43.

Edwards, J. (2007), 'Challenges and opportunities for the internationalization of higher education in the coming decade: Planned and opportunistic initiatives in American institutions', Journal of Studies in International Education 11, nos. 3-4: 373-381. https://doi.org/10.1177/1028315307303920.

Egeberg, M. (2012), 'How bureaucratic structure matters: an organizational perspective', in G. B. Peters and J. Pierre (eds), The Sage Handbook of Public Administration, 2nd ed. (London: Sage), 157-168.

Finkelstein, M. J., E. Walker and R. Chen (2013), 'The American faculty in an age of globalization: Predictors of internationalization of research content and professional networks', Higher Education 66, no. 3: 325-340. https://doi.org/10.1007/ s10734-012-9607-3. 
Fumasoli, T. (2015a), 'Handling uncertainty of strategic ambitions: The use of organizational identity as a risk-reducing device', International Journal of Public Administration 38, nos. 13-14: 1030-1040. https://doi.org/10.1080/01900692 .2014.988868.

Fumasoli, T. (2015b), 'Multilevel governance in higher education research', in J. Huisman, H. de Boer, D. D. Dill and M. Souto-Otero (eds), The Palgrave International Handbook of Higher Education Policy and Governance (New York: Palgrave Macmillan).

Fumasoli, T., Å. Gornitzka and P. Maassen (2014), University Autonomy and Organizational Change Dynamics (Oslo: University of Oslo).

Fumasoli, T. and J. Huisman (2013), 'Strategic agency and system diversity: conceptualizing institutional positioning in higher education', Minerva 51, no. 2: 155-169. https://doi.org/10.1007/s11024-013-9225-y.

Fumasoli, T., R. Pinheiro and B. Stensaker (2015), 'Handling uncertainty of strategic ambitions: The use of organizational identity as a risk-reducing device', International Journal of Public Administration 38, nos. 13-14: 1030-1040. https://doi.org/10.1080/ 01900692.2014 .988868$.

Gieser, J. D. (2016), 'An international academic partnership through a policy implementation lens: Top-down, bottom-up or somewhere in between?', FIRE: Forum for International Research in Education 2, no. 3: 62-78. https://doi.org/10.18275/ fire201602031094.

Hayes, N. (2000), Doing Psychological Research: Gathering and Analysing Data (Buckingham: Open University).

Hooghe, L. and G. Marks (2001), Multi-Level Governance and European Integration (Lanham/Boulder/New York/Oxford: Rowman \& Littlefield).

Horta, H. and M. T. Patrício (2016), 'Setting-up an international science partnership program: A case study between Portuguese and US research universities', Technological Forecasting and Social Change 113: 230-239. https://doi.org/10.1016/ j.techfore.2015.07.027.

Hudzik, J. K. (2015), 'Strategic institutional partnerships and comprehensive internationalisation', in N. Jooster, H. de Wit and S. Heleta (eds), Higher Education: Partnerships for the Future (Porto Elizabeth: Unit for Higher Education Internationalisation in the Developing World), 23-39.

Hunter, F. (2018), 'Training administrative staff to become key players in the internationalization of higher education', International Higher Education 92: 16-17. https://doi.org/ 10.6017/ihe.2018.92.10280.

Jones, G. A. and A. Oleksiyenko (2011), 'The internationalization of Canadian university research: A global higher education matrix analysis of multi-level governance', Higher Education, 61, no. 1: 41-57. https://doi.org/10.1007/s10734-010-9324-8.

Knight, J. (2004), 'Internationalization remodeled: Definition, approaches, and rationales', Journal of Studies in International Education 8, no. 1: 5-31. https://doi.org/ $10.1177 / 1028315303260832$. 
Knight, J. (2008), 'The internationalization of higher education: complexities and realities', in D. Teferra and J. Knight (eds), Higher Education in Africa: The International Dimension (Boston: Center for International Higher Education, Boston College and Association of African Universities), 1-43.

Knight, J. and H. de Wit (1997), Internationalisation of Higher Education in Asia Pacific Countries (Amsterdam: European Association for International Education).

March, J. G. (1999), 'A learning perspective on the network dynamics of institutional integration', in M. Egeberg and P. Lægreid (eds), Organizing Political Institutions (Oslo: Scandinavian University Press), 129-155.

March, J. G. and J. P. Olsen (1976), Rediscovering Institutions. The Organizational Basis of Politics (New York: Collier Macmillan).

March, J. G. and J. P. Olsen (2006), 'The logic of appropriateness', in M. Moran, M. Rein and R. E. Goodin (eds), The Oxford Handbook of Public Policy (Oxford: Oxford University Press), 689-708.

March, J. G. and H. Simon (1993), Organizations, 2nd ed. (Oxford: Blackwell Publishers).

Marginson, S. and G. Rhoades (2002), 'Beyond national states, markets, and systems of higher education: A glonacal agency heuristic', Higher Education 43, no. 3: 281-309. https://doi.org/10.1023/A:1014699605875.

Marks, G. (1992), 'Structural policy in the European community', in A. Sbragia (ed.), Euro-politics: Institutions and Policymaking in the "New" European Community (Washington: The Brookings Institution), 191-224.

Marks, G. (1993), 'Structural policy and multi-level governance in the EC', in A. Cafruny and G. Rosenthal (eds), The State of the European Community. Vol.2: The Maastricht Debate and Beyond (Harlow, Essex: Longman and Boulder: Lynne Rienner), 391-410.

Miles, M. B., A. M. Huberman, M. A. Huberman and M. Huberman (1994), Qualitative Data Analysis: An Expanded Sourcebook, 2nd ed., (Thousand Oaks: Sage).

Ministry of Science, Technology and Innovation (2009), Danish University Evaluation 2009: Evaluation Report (Copenhagen: The Danish University and Property Agency).

Neave, G. (1992), Managing Higher Education International Cooperation: Strategies and Solutions, unpublished reference document for UNESCO, Paris.

Oddershede, J. (2009), Danish Universities: A Sector in Change (Copenhagen: Universities Denmark).

Oleksiyenko, A. (2009), 'Global Portfolios and Strategic International Partnerships of a Major Research University' (Ph.D. thesis, Department of Theory and Policy Studies in Education, Ontario Institute for Studies in Education, University of Toronto).

Preymann, S., S. Sterrer, B. Ehrenstorfer, M Gaisch and R. Aichinger, (2016), 'Harmonising the interface between academic and administrative mind-sets: challenging but feasible?', in C. Sarrico, P. Teixeira, A. Magalhães, A. Veiga, M. J. Rosa and T. Carvalho (eds), Global Challenges, National Initiatives, and Institutional Responses: The Transformation of Higher Education (Rotterdam: Sense Publishers), 237-265. 
Ryttberg, M. and L. Geschwind (2017), 'Professional support staff at higher education institutions in Sweden: Roles and success factors for the job', Tertiary Education and Management 23, no. 4: 334-346. https://doi.org/10.1080/13583883.2017.1322631.

Scott, W. R. (2003), Organization: Rational, Natural, and Open Systems, 5th ed. (Cranbury: Pearson Education International).

Scott, W. R. (2008), Institutions and Organizations, Ideas and Interests (Thousand Oaks, CA: Sage).

Seeber, M., B. Lepori, M. Montauti, J. Enders, J. H. De Boer, E. Weyer, ... G. N. Mathisen (2015), 'European universities as complete organizations? Understanding identity, hierarchy and rationality in public organizations', Public Management Review 17, no. 10: 1444-1474. https://doi.org/10.1080/14719037.2014.943268.

Simon, H. (1965), Administrative Behavior: A Study of Decision-Making Processes in Administrative Organization, 2nd ed. (New York: Free Press).

Spencer-Oatey, H. (2013), 'Maximizing the benefits of international education collaborations: Managing interaction processes', Journal of Studies in International Education 17, no. 3: 244-261. https://doi.org/10.1177/1028315312454545.

Tekleselassie, A. and A. Ford (2019), 'Planning and implementing a mutually beneficial international university partnership in educational leadership between us and Middle Eastern institutions', International Journal of Educational Reform 28, no. 2: 179-206. https://doi.org/10.1177/1056787919841500.

University World News (2010), 'DENMARK: Huge doctorate expansion continues', 21 February, http://www.universityworldnews.com/article.php?story = 20100219130054997.

Wright, S. (2014), Knowledge that Counts: Points Systems and the Governance of Danish Universities: Governance on the Front Line (Toronto: University of Toronto Press).

Yin, R. K. (2003), Case Study Research: Design and Methods, 3rd ed. (Thousand Oaks, CA: Sage).

Zha, Q. (2003), 'Internationalization of higher education: towards a conceptual framework', Policy Futures in Education 1, no. 2: 248-270. https://doi.org/10.2304/ pfie.2003.1.2.5. 